ISSN 1678-3921

Journal homepage: www.embrapa.br/pab

For manuscript submission and journal contents, access: www.scielo.br/pab

\section{Occurrence of rice blast on and grain quality of irrigated rice fertilized with nitrogen and silicates}

\begin{abstract}
The objective of this work was to evaluate the effects of fertilization with nitrogen topdressing and silicates, as well as of the use of fungicides, on the occurrence of rice blast on panicles, milling yield, and whole grains, vitreous grains, and chalky kernels in a flood-irrigated rice cultivar sensitive to the disease. Two experiments were conducted in a randomized complete block design, in a $4 \times 4 \times 2$ factorial arrangement, with four replicates: in experiment 1 , four doses of nitrogen $\times$ four doses of calcium and magnesium silicate on soil $\times$ with and without fungicides; and, in experiment 2 , four doses of nitrogen $\times$ four doses of potassium silicate applied on leaves $\mathrm{x}$ with and without fungicides. At the doses above $60 \mathrm{~kg} \mathrm{ha}^{-1}$ nitrogen without fungicides, there was an increase of rice blast severity on panicles, a decrease in the percentage of whole and vitreous grains, and an increase in chalky kernels and chalky area. The greatest effects of silicates occurred without fungicides. Fungicide use reduced the severity of rice blast on panicles. Milling yield ranged from 60 to $70 \%$ in both experiments. The control of rice blast with fungicides maintains high rice grain quality, milling yield, and percentages of whole and vitreous grains.
\end{abstract}

Index terms: Oryza sativa, Pyricularia oryzae, grain yield, whole grains.

\section{Ocorrência de brusone e qualidade de grãos em arroz irrigado adubado com nitrogênio e silicatos}

Resumo - O objetivo deste trabalho foi avaliar os efeitos da adubação com nitrogênio em cobertura e silicatos, bem como da utilização de fungicidas, sobre a ocorrência de brusone nas panículas, a renda do benefício e os grãos inteiros, vítreos e gessados, em cultivar de arroz irrigado por inundação sensível à doença. Foram conduzidos dois experimentos em delineamento de blocos ao acaso, em arranjo fatorial $4 \times 4 \times 2$, com quatro repetições: no experimento 1 , quatro doses de nitrogênio $\times$ quatro doses de silicato de cálcio $\mathrm{e}$ magnésio via solo $\times$ com e sem uso de fungicidas; e, no experimento 2 , quatro doses de nitrogênio $\times$ quatro doses de silicato de potássio via foliar $\times$ com e sem fungicidas. Nas doses acima de $60 \mathrm{~kg} \mathrm{ha}^{-1}$ de nitrogênio sem fungicidas, houve aumento da severidade de brusone nas panículas, redução do percentual de grãos inteiros e vítreos, e aumento de grãos gessados e área gessada. Os maiores efeitos dos silicatos ocorreram sem aplicações de fungicidas. $\mathrm{O}$ uso de fungicidas reduziu a severidade de brusone nas panículas. A renda do benefício oscilou entre 60 e 70\%, em ambos os experimentos. O controle da brusone com fungicidas mantém elevadas a qualidade de grãos do arroz, a renda do benefício e as percentagens de grãos inteiros e vítreos.

Termos para indexação: Oryza sativa, Pyricularia oryzae, rendimento do grão, grãos inteiros. 


\section{Introduction}

Rice (Oryza sativa L.) is one of the most important cereals for the world population and much of its consumption is in the form of whole milled kernels. Therefore, grain quality is a characteristic that determines the value paid to the producer and is a decisive factor for the consumer at the time of purchase (Fang et al., 2015).

The physical quality of the grain, expressed by milling yield, whole grains, and grain dimensions and characteristics, steers the commercialization process (Mingotte et al., 2012). According to the Brazilian legislation, milling yield is considered as the percentage of milled rice or of milled and polished rice, resulting from the rice milling process (Brasil, 2009). In the Brazilian market, the preference is for grains with a high milling yield of over $70 \%$, without defects and with a high whole grain yield above $60 \%$ (Reunião Técnica..., 2018). The characteristics of whole grains, vitreous grains, and chalky kernels, as well as staining defects, are affected by physiological disturbances caused by biotic or abiotic factors and result in the depreciation of the final product (Streck et al., 2018). Therefore, the improvement of grain quality is one of the main selection criteria in breeding programs.

The increase in productivity and grain quality, however, requires a greater use of agricultural inputs and an adequate management of the crop, which increases the cost of production. One of the items with the largest participation in this cost is the management of basic fertilization and topdressing (Irga, 2018) due to the greater requirement of nitrogen, one of the most limiting nutrients to the crop (Ahmed et al., 2016). However, the supply of $\mathrm{N}$ at high doses may increase the susceptibility of plants to rice blast (Huang et al., 2017), whose causal agent, the fungal pathogen Pyricularia oryzae, attacks all the organs of the plant and can cause damages of up to $100 \%$ in rice production throughout the world (Ou, 1985; Bregaglio et al., 2016). Therefore, since the reduction of grain yield is correlated with the severity of rice blast, there is a great effort of researchers to carry out studies on how to control the disease (Hossain et al., 2017).

Although the use of fungicides is the main form of rice blast control, the demand for more sustainable practices in the field makes the use of silicates a promising proposal to minimize or complement chemical control. The use of silicates via soil or foliar fertilization aims to provide silicon for crops, and, in some cases, calcium, magnesium, and potassium. These elements are important because they are associated with factors beneficial to plants, such as greater structural rigidity of tissues that increases the mechanical resistance of cells, lower self-shading, and protection against biotic stresses due to the reduction in the incidence of pathogens (Lima et al., 2011).

It should be noted that works on the effects of the association between N, Si, and fungicide applications on the industrial quality of irrigated rice grains are still scarce. Some studies have related grain quality to factors such as different humidity levels and fungicide use (Teló et al., 2011), irrigation suppression (Londero et al., 2015), high temperature (Nakata et al., 2017), and shading (Deng et al., 2018).

The objective of this work was to evaluate the effects of fertilization with nitrogen topdressing and silicates, as well as of the use of fungicides, on the occurrence of rice blast on panicles, milling yield, and whole grains, vitreous grains, and chalky kernels in an irrigated rice cultivar sensitive to the disease.

\section{Materials and Methods}

Two experiments were installed in the paddy field, during the 2014/2015 crop season, in the experimental area of the Department of Plant Science of Universidade Federal de Santa Maria, located in the state of Rio Grande do Sul, Brazil $\left(29^{\circ} 43^{\prime} \mathrm{S}, 53^{\circ} 43^{\prime} \mathrm{W}\right.$, at $90 \mathrm{~m}$ of altitude). The local climate is Cfa, subtropical humid, according to Köppen-Geiger's classification, adapted from Alvares et al. (2013), without a dry season and with the average temperature of the hottest month exceeding $22^{\circ} \mathrm{C}$. The air temperature and precipitation during the experimental period are shown in Figure 1. The soil is classified as a Planossolo Háplico eutrófico arênico(Santos etal., 2013),i.e., a sandy Eutrophic Haplic Alfisol, with the following chemical characteristics: $\mathrm{pH}_{\mathrm{H} 2 \mathrm{O}}(1: 2: 5) 6.0,1.7 \mathrm{dag}^{\mathrm{kg}^{-1}}$ organic matter, 23 $\mathrm{mg} \mathrm{dm}{ }^{-3}$ P-Mehlich-1, $49 \mathrm{mg} \mathrm{dm}{ }^{-3} \mathrm{~K}, 5.0 \mathrm{cmol}_{\mathrm{c}} \mathrm{dm}^{-3}$ $\mathrm{Ca}, 0.2 \mathrm{cmol}_{\mathrm{c}} \mathrm{dm}^{-3} \mathrm{Mg}, 9.0 \mathrm{cmol}_{\mathrm{c}} \mathrm{dm}^{-3} \mathrm{~S}, 0.0 \mathrm{cmol}_{\mathrm{c}} \mathrm{dm}^{-3}$ $\mathrm{Al}, 6.0 \mathrm{mg} \mathrm{dm}^{-3} \mathrm{Si}_{\mathrm{CaCl}}, \mathrm{Al}$ saturation of $0.0 \%$, and base saturation of $65.5 \%$.

The experimental design was a randomized complete block, in a $4 \times 4 \times 2$ factorial arrangement with four replicates. In experiment 1 , the treatments were composed of four $\mathrm{N}$ doses $\left(0,60,120\right.$, and $\left.180 \mathrm{~kg} \mathrm{ha}^{-1}\right)$ 
applied as topdressing, of four $\mathrm{Ca}$ and $\mathrm{Mg}$ silicate doses (85\% effective $\mathrm{Ca}$ carbonate equivalent, $25 \%$ $\mathrm{Ca}, 6 \% \mathrm{Mg}, 10.5 \% \mathrm{Si}$, and $22.4 \% \mathrm{SiO}_{2}$, the product is a steel residue, derived from stainless steel slag) applied to the soil surface without incorporation at the time of sowing $0,3,000,6,000$, and $9,000 \mathrm{~kg} \mathrm{ha}^{-1}$ seeds, and the use or not of the mixture of fungicides with tricyclazole, azoxystrobin, and difenoconazole as active ingredients. In experiment 2, the treatments were composed of four $\mathrm{N}$ doses applied as topdressing $\left(0,60,120\right.$, and $\left.180 \mathrm{~kg} \mathrm{ha}^{-1}\right)$ and four $\mathrm{K}$ silicate doses $\left[\mathrm{K}_{2} \mathrm{SiO}_{3}\left(10 \% \mathrm{Si}, 24 \% \mathrm{~K}_{2} \mathrm{O}\right.\right.$, and a density of $\left.\left.1.41 \mathrm{~g} \mathrm{~cm}^{-3}\right)\right]$ applied on leaves $\left(0.0,2.9,5.8\right.$, and $\left.8.7 \mathrm{~L} \mathrm{ha}^{-1}\right)$, with a stem volume of $135 \mathrm{~L} \mathrm{ha}^{-1}$ and the use or not of the same fungicide mixture of experiment 1.

For both experiments, all management practices followed the technical recommendations for floodirrigated rice cultivation (Reunião Técnica..., 2014), except the applied treatments. The cultivar used was Guri INTA CL, with a medium cycle of 125 to 130 days, susceptibility to rice blast, and high grain quality. Seeding was performed on December 8, 2014, at a density of $80 \mathrm{~kg} \mathrm{ha}^{-1}$ seeds, in the minimum tillage system. Each plot was formed by nine rows spaced at $0.17 \mathrm{~m}$, totaling $3,825 \mathrm{~m}^{2}$. Basic fertilization was carried out in the sowing line with $16 \mathrm{~kg} \mathrm{ha}^{-1} \mathrm{~N}, 68 \mathrm{~kg}$ $\mathrm{ha}^{-1} \mathrm{P}_{2} \mathrm{O}_{5}$, and $108 \mathrm{~kg} \mathrm{ha}^{-1} \mathrm{~K}_{2} \mathrm{O}$. For topdressing, urea was used as the source of $\mathrm{N}$ - two thirds of the doses were applied in the $\mathrm{V}_{3} / \mathrm{V}_{4}$ stage and the remainder in $\mathrm{R}_{0}$, according to the scale proposed by Counce et al. (2000). The fungicides were applied four times, when the first blast spots appeared, between the $\mathrm{V}_{6}$ and $\mathrm{V}_{7}$ growth stages, by spraying 225,100 , and 50 g a.i. ha ${ }^{-1}$, respectively, of the mixture of tricyclazole, azoxystrobin, and difenoconazole. For this, a backpack sprayer propelled by $\mathrm{CO}_{2}$, with a pressure of $40 \mathrm{lbs} \mathrm{pol}^{-2}$ and $135 \mathrm{~L} \mathrm{ha}^{-1}$ stem volume, with the addition of $0.5 \%$ $\mathrm{v} / \mathrm{v}$ emulsifiable mineral oil, was used.

Panicle blast severity was measured at the $\mathrm{R}_{8}$ growth stage, using a scale of 0 to $100 \%$ on $1 \mathrm{~m}$ of the second seeding line (Silva-Lobo et al., 2012). Milling yield was considered the percentage of milled and polished rice obtained by weighing the grains after processing $100 \mathrm{~g}$ rice with husk (Brasil, 2009); using a ricetesting machine to test rice samples. The percentage of whole grains was calculated according to the method described in Teló et al. (2011).

The variables related to grain quality (vitreous grains, white-belly grains, chalky kernels, and chalky area) were evaluated using the S21 statistical rice analyzer (iSuzuki Software, Santa Cruz do Rio Pardo, SP, Brazil). Coupled to a computer, this equipment captures and processes images that analyze the individual grains using a digital image analysis software to calculate grain quality parameters; after sample processing, it provides reports to the equipment

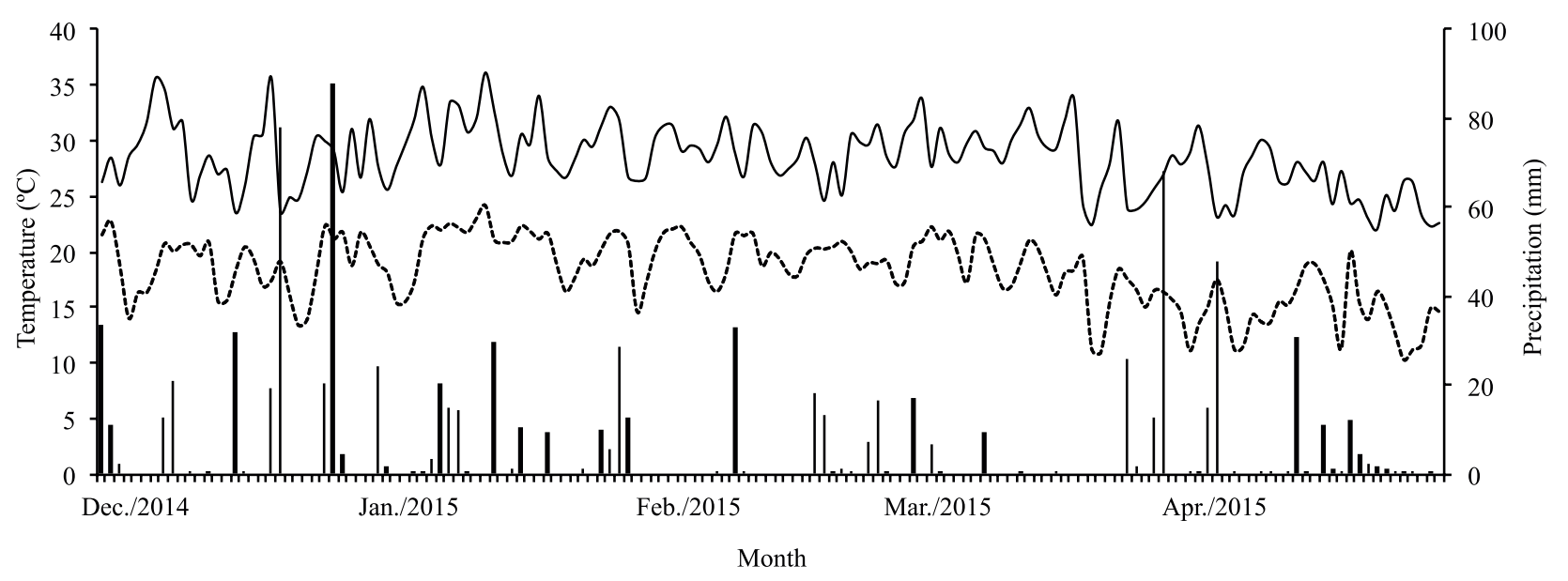

Precipitation $(\mathrm{mm})$

Maximum temperature $\left({ }^{\circ} \mathrm{C}\right)$

Minimum temperature $\left({ }^{\circ} \mathrm{C}\right)$

Figure 1. Maximum and minimum air temperature, and rainfall in the experimental period during the 2014/2015 rice (Oryza sativa) crop season in the municipality of Santa Maria, in the state of Rio Grande do Sul, Brazil. 
operator. The software considers vitreous grains as those with less than $25 \%$ chalky area, chalky grains as those with $70 \%$ or more chalky area, and whitebelly grains as those with a chalky area that represents between 40 and $70 \%$ of the grain surface.

The results of the experiments were subjected to the tests of assumptions of the mathematical model for normality and homogeneity of variances. The analysis of variance was performed using the F-test. The means were subjected to the polynomial regression analysis, and the confidence interval of $p \leq 0.05$ was determined. The data of the variables panicle blast severity and chalky kernels, for both experiments, and of whitebelly grains, for experiment 1, were transformed according to the equation: $y t=\sqrt{(y+0.5) / 100}$.

\section{Results and Discussion}

The climatic conditions in the 2014/2015 crop season (Figure 1), such as temperature and frequent rains, were one of the factors that favored the occurrence of rice blast. When fungicides were applied, the percentages of disease severity were lower than $2 \%$, regardless of the $\mathrm{N}$ dose used (Figure 2). However, when the rice plants were not treated with fungicides, the effect of $\mathrm{N}$ doses on panicle blast severity differed. There was an increase in severity with the highest doses, with a mean of $3,3,56$, and $67 \%$ panicle blast severity for $0,60,120$, and $180 \mathrm{~kg} \mathrm{ha}^{-1} \mathrm{~N}$, respectively. The lower incidence of the disease with the lower $\mathrm{N}$ doses could be explained by the lower development of the aerial part of the plants, which may have decreased humidity between lines and created unfavorable conditions for the fungus. Huang et al. (2017) also found increased rice blast severity with high levels of $\mathrm{N}$ fertilization. With the higher availability of nutrients due to this fertilization, the fungus is able to detect the metabolic modifications of the host when in contact with the leaf surface, accelerating its growth. In this case, the susceptibility to fungicides with systemic activity allows protecting the plants from infection by reducing mycelial growth and the germination of conidia (Chen et al., 2015; Pak et al., 2017). In studies conducted in China, the fungicide azoxystrobin presented more than $73 \%$ efficacy in rice blast control (Chen et al., 2015).

There was an interaction between $\mathrm{N}, \mathrm{Ca}$, and $\mathrm{Mg}$ silicate doses and fungicides in the percentage of milling yield, whole grains, and vitreous grains
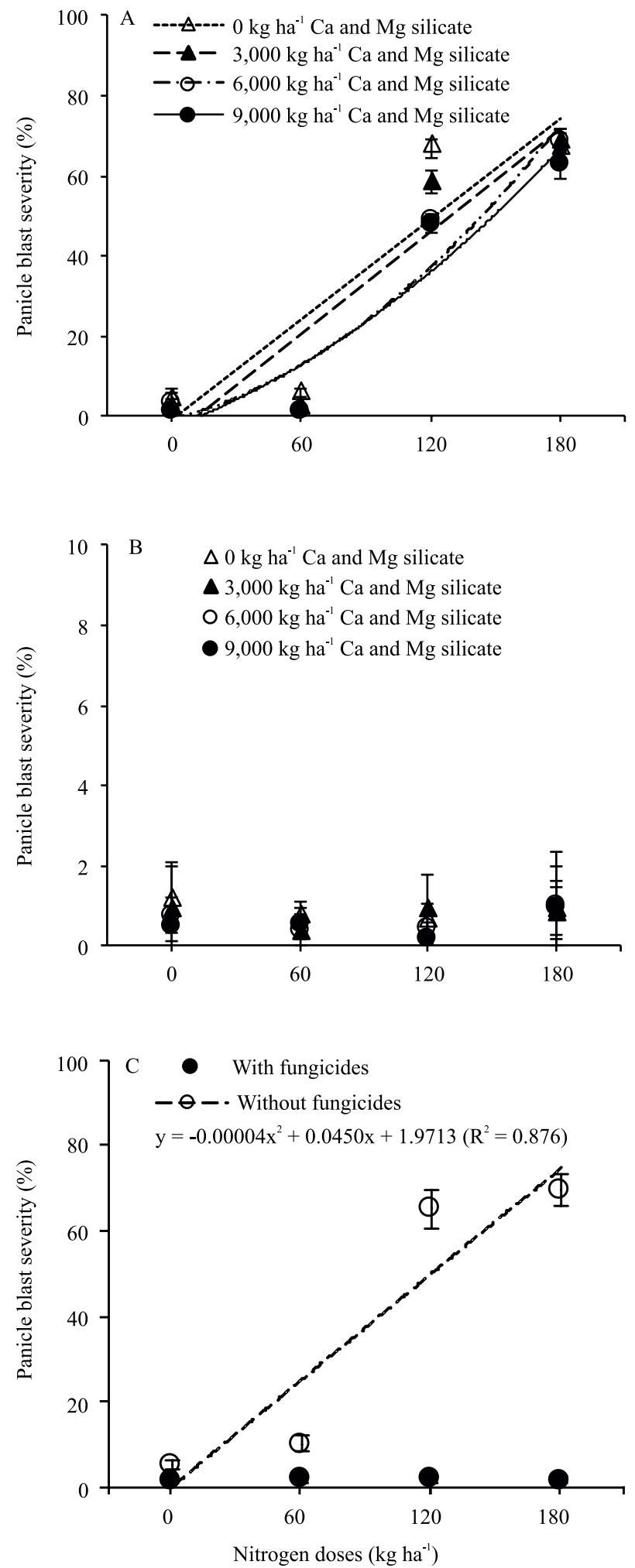

Figure 2. Panicle blast severity in the Guri INTA CL floodirrigated rice (Oryza sativa) cultivar, according to doses of nitrogen and calcium and magnesium silicate (A and $B$ ), and potassium silicate $(\mathrm{C})$, without $(\mathrm{A})$ and with $(\mathrm{B})$ fungicide applications in the 2014/2015 crop season. 

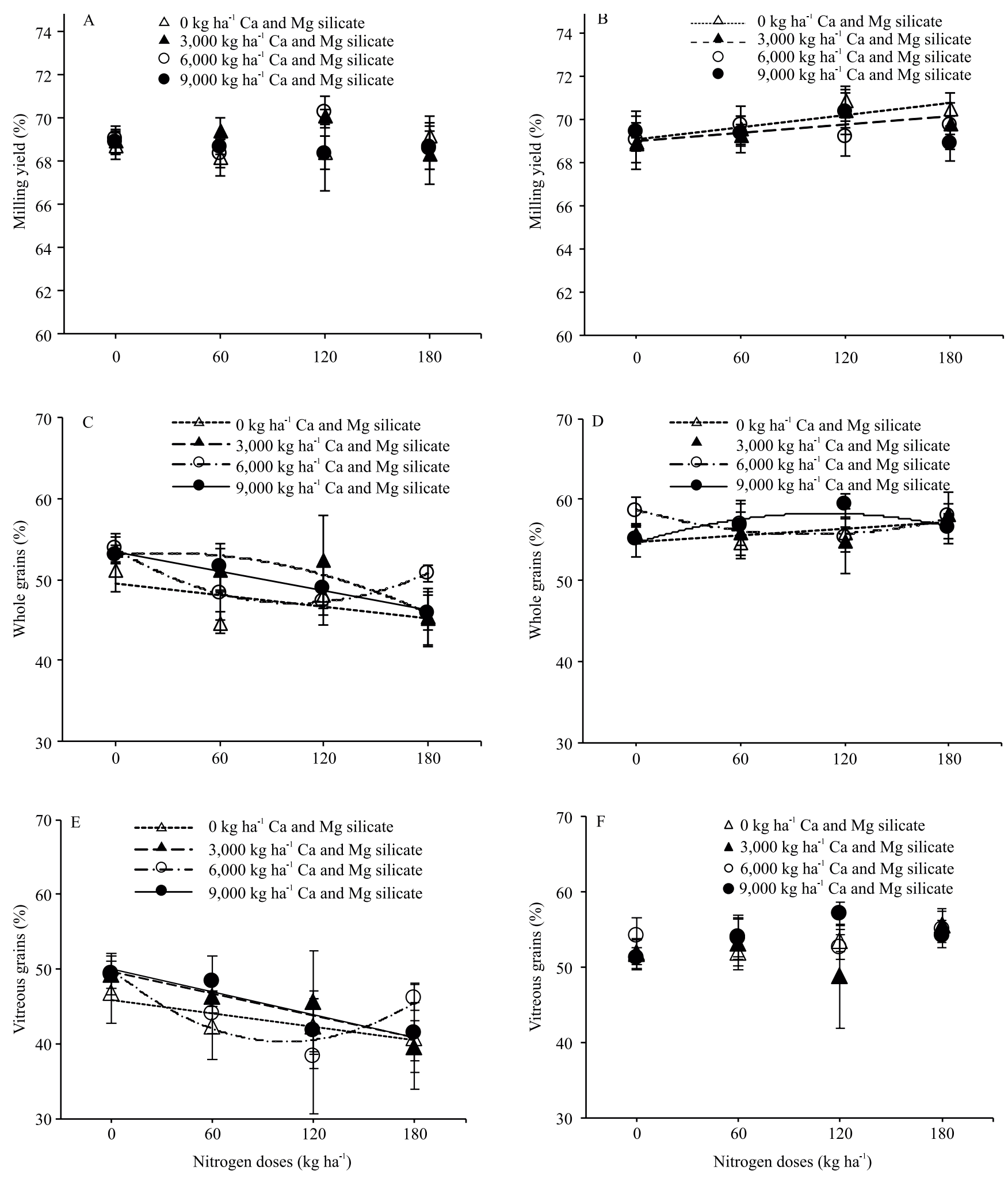

Figure 3. Milling yield (A and B), whole grains (C and D), and vitreous grains (E and F) for the Guri INTA CL floodirrigated rice (Oryza sativa) cultivar, according to doses of nitrogen, calcium, and magnesium silicate, without (A, C, and E) and with (B, D, and F) fungicide applications in the 2014/2015 crop season. 
(Figure 3). The values for milling yield, regardless of the application or not of fungicides, remained between 68 and $71 \%$. However, the high rice blast severity index presented in the crop's vegetative development stage directly affected grain filling, resulting in a lower rice grain quality. This justifies the decrease in the percentage of whole grains with the increase of $\mathrm{N}$ doses, which, without fungicide application, increased the amount of broken grains. Groth (2006) concluded that rice plants with panicle blast severity from 32 to $69 \%$ showed whole grain parameters and milling yield with values considered inferior to the commercial standards of 55 and $70 \%$, respectively; however, it should be noted that under conditions of low disease pressure, the values obtained in the present study are acceptable. The same author, when evaluating the M202 cultivar, which is very susceptible to rice blast, observed a reduction of $23 \%$ in whole grain yield when fungicides were not used for disease control. This happens because rice blast, especially of the neck, compromises the ability of the plant to transport nutrients to the panicles, which affects grain filling.

The percentage of whole grains remained from 55 to $60 \%$ with the use of fungicides, but decreased to 45 to $54 \%$ when no fungicides were applied (Figure 3). A similar pattern was observed for vitreous grains, whose percentage varied from 49 to $57 \%$ with the use of fungicides and from 30 to $49 \%$ without their application. There was a difference between the doses of silicates in the absence of fungicides, and the values of both vitreous and whole grains were lower than those obtained with fungicide use, which resulted in the highest percentages. The lowest percentages of 38.42 and $39.67 \%$ vitreous grains were found in plants without fungicides, in the combinations of $120 \mathrm{~kg} \mathrm{ha}^{-1}$ $\mathrm{N}$ with $6,000 \mathrm{~kg} \mathrm{ha}^{-1} \mathrm{Ca}$ and $\mathrm{Mg}$ silicate and of $180 \mathrm{~kg}$ $\mathrm{ha}^{-1} \mathrm{~N}$ with $3,000 \mathrm{~kg} \mathrm{ha}^{-1}$ silicates, respectively. Similar results were reported by Artigiani et al. (2012) and Reis et al. (2008), who did not find that the application of these silicates affected milling yield and whole grains. A possible explanation is that the Si available in the soil may have supplied the needs of the rice plants (Artigiani et al., 2012).

The use of fungicides was efficient in panicle blast control and maintained the amounts of whole and vitreous grains. This happened because in the $\mathrm{R}_{5}$ to $\mathrm{R}_{9}$ stages, when grain filling occurs, the leaves and panicles were healthy. When blast attacks the knot below the panicle, it can interrupt the flow of photoassimilates to the grains, which interferes with their filling and mass, causing greater losses in productivity (Hao et al., 2014).

The white belly and chalky kernel parameters were influenced by the doses of $\mathrm{N}, \mathrm{Ca}$, and $\mathrm{Mg}$ silicate, as well as by the fungicides (Figure 4). Regarding these characteristics, a better grain quality was found in the treatments that received fungicide application. The defect white-belly grains was observed at an average of 3 to $9 \%$ and of 0.8 to $4 \%$, without and with the application of fungicides, respectively. The lowest percentage of $0.8 \%$ was a result of the combination of 120 and $180 \mathrm{~kg} \mathrm{ha}^{-1} \mathrm{~N}$, with the application of fungicides and without the application of silicates.

Silicate application did not reduce the percentage of grains (Figure 4), since, at the dose of $9,000 \mathrm{~kg} \mathrm{ha}^{-1} \mathrm{Ca}$ and $\mathrm{Mg}$ silicate with the application of 120 and $180 \mathrm{~kg}$ ha $^{-1} \mathrm{~N}$, there was an increase in grains. Korndörfer \& Datnoff (1995), however, found that the use of Si in crops efficiently controls or minimizes the incidence of diseases. Chalky area was also affected by increased $\mathrm{N}$ doses and fungicide application, which resulted in a lower chalky area. Similar results were obtained by Grigg et al. (2016). The data of the variables milling yield, whole grains, vitreous grains, chalky kernels, and white-belly grains had linear and quadratic adjustments (Table 1).

There was a triple interaction between all treatments only for milling yield, with values ranging from 60 to $71 \%$ (Figure 5 and Table 2). In the absence of fungicides, there were different responses to $\mathrm{K}$ silicate applications, without increases in milling yield when the doses of $\mathrm{N}$ and $\mathrm{K}$ silicate were increased. In fact, the lowest percentages of milling yield were observed for $8.7 \mathrm{~L}$ $\mathrm{ha}^{-1} \mathrm{~K}_{2} \mathrm{SiO}_{3}$. This can be explained by the difference in the absorption of the applied product by the leaves and the architecture of the plants at the moment of application, among other factors that compromise foliar absorption (Fernández \& Brown, 2013).

The percentage of whole grains was influenced by $\mathrm{N}$ fertilization, by the doses of $\mathrm{K}$ silicate, and by the interaction between $\mathrm{N}$ doses and fungicide applications (Figure 5). Regardless of the $\mathrm{N}$ doses, the percentage of whole grains remained at $56 \%$ for plants that received fungicides. However, the percentage of vitreous grains was only affected by $\mathrm{N}$ doses and 

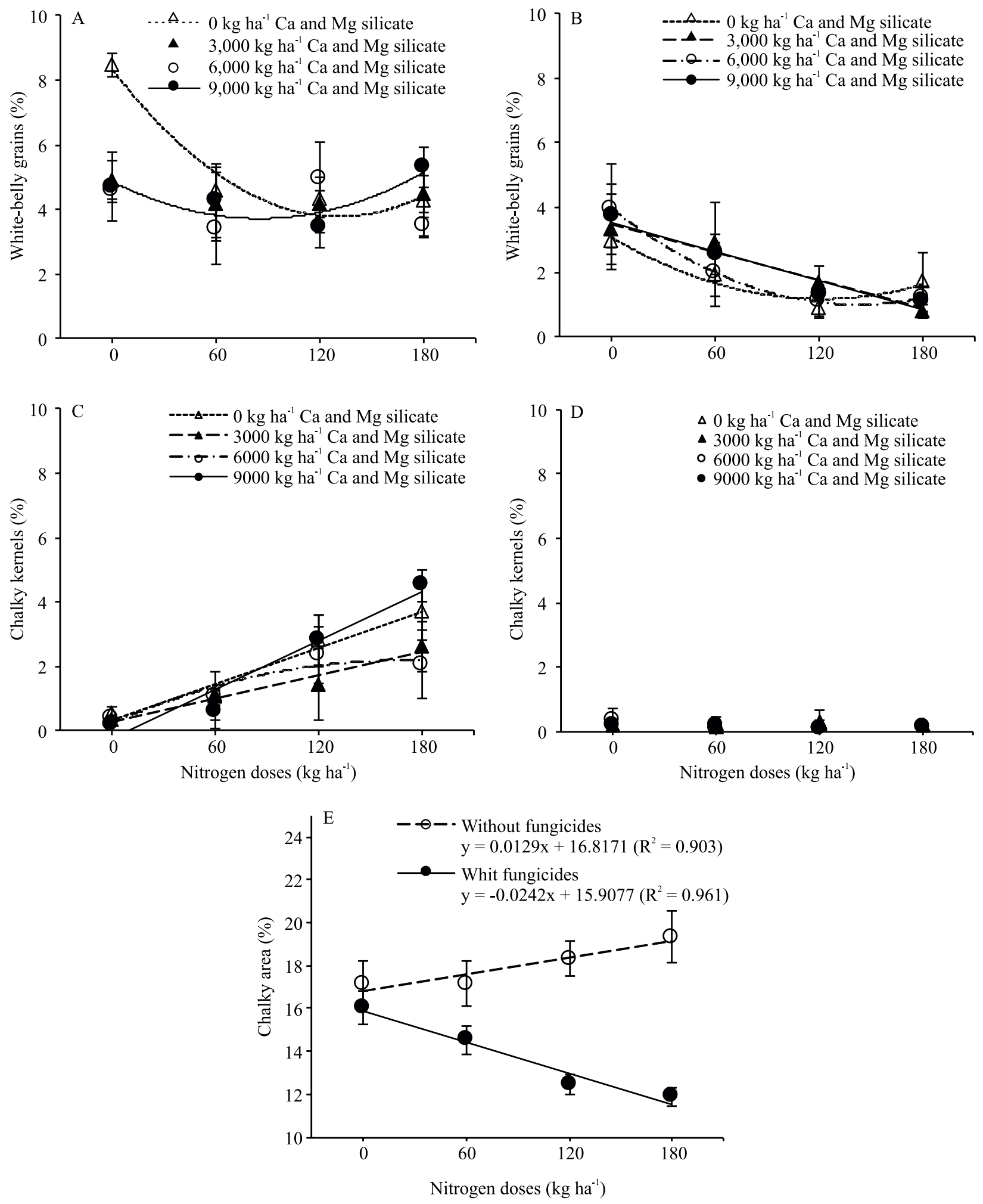

Figure 4. White-belly grains (A and B), chalky kernels (C and D), and chalky area (E) for the Guri INTA CL flood-irrigated rice (Oryza sativa) cultivar, according to doses of nitrogen, calcium, and magnesium silicate, without (A and C) and with (B and D) fungicide applications in the 2014/2015 crop season. 
fungicide applications. The absence of fungicides caused a decrease in vitreous grains with increasing $\mathrm{N}$ doses, with the lowest value of $37 \%$ at the doses of 120 and $180 \mathrm{~kg} \mathrm{ha}^{-1} \mathrm{~N}$. When fungicides were applied to the rice plants, higher percentages of milling yield and of whole and vitreous grains were obtained with constant values, regardless of the use of $\mathrm{K}$ silicate. Bordin et al. (2016), while evaluating the application of fungicides at different phenological stages of irrigated rice cultivars, reported that, when the disease was less severe, there was a higher percentage of milling yield and whole grains.

The combined action of $\mathrm{N}, \mathrm{K}$ silicate, and fungicides was only observed in white-belly grains, with a chalky area between 40 and $70 \%$ of the surface (Figure 6). The lowest percentages of white-belly grains ranged from 1.0 to 3.6 and the highest ones from 1.7 to 7.0, with and without the use of fungicides, respectively. There was no difference between doses of $\mathrm{K}$ silicate regarding the occurrence or reduction of white-belly

Table 1. Equations and coefficients of determination $\left(\mathrm{R}^{2}\right)$ of the used regressions, according to nitrogen, calcium, and magnesium silicate doses and to fungicides applied to the Guri INTA CL flood-irrigated rice (Oryza sativa) cultivar.

\begin{tabular}{|c|c|c|c|c|}
\hline \multirow[t]{2}{*}{ Treatment } & \multicolumn{2}{|l|}{ Without fungicide application } & \multicolumn{2}{|l|}{ With fungicide application } \\
\hline & Equation & $\mathrm{R}^{2}$ & Equation & $\mathrm{R}^{2}$ \\
\hline & \multicolumn{4}{|c|}{ Panicle blast severity (\%) } \\
\hline $0 \mathrm{~kg} \mathrm{ha}^{-1} \mathrm{Ca}$ and $\mathrm{Mg}$ silicate & $\mathrm{y}=0.0394 \mathrm{x}+1.8037^{*}$ & 0.817 & ns & - \\
\hline 3,000 $\mathrm{kg} \mathrm{ha}^{-1} \mathrm{Ca}$ and $\mathrm{Mg}$ silicate & $y=0.0431 x+0.9967 *$ & 0.844 & $\mathrm{~ns}$ & - \\
\hline 6,000 $\mathrm{kg} \mathrm{ha}^{-1} \mathrm{Ca}$ and $\mathrm{Mg}$ silicate & $\mathrm{y}=0.0001 \mathrm{x}^{2}+0.0190 \mathrm{x}+1.2631 *$ & 0.846 & $\mathrm{~ns}$ & - \\
\hline \multirow[t]{2}{*}{ 9,000 $\mathrm{kg} \mathrm{ha}^{-1} \mathrm{Ca}$ and $\mathrm{Mg}$ silicate } & $y=0.00007 x^{2}+0.0299 x+0.7719^{*}$ & 0.860 & $\mathrm{~ns}$ & - \\
\hline & \multicolumn{4}{|c|}{ Milling yield (\%) } \\
\hline $0 \mathrm{~kg} \mathrm{ha}^{-1} \mathrm{Ca}$ and $\mathrm{Mg}$ silicate & $\mathrm{ns}$ & - & $y=0.0095 x+69.0683^{*}$ & 0.765 \\
\hline 3,000 $\mathrm{kg} \mathrm{ha}^{-1} \mathrm{Ca}$ and $\mathrm{Mg}$ silicate & ns & - & $y=0.0062 x+68.9900^{*}$ & 0.534 \\
\hline $6,000 \mathrm{~kg} \mathrm{ha}^{-1} \mathrm{Ca}$ and $\mathrm{Mg}$ silicate & ns & - & ns & - \\
\hline \multirow[t]{2}{*}{ 9,000 $\mathrm{kg} \mathrm{ha}^{-1} \mathrm{Ca}$ and $\mathrm{Mg}$ silicate } & ns & - & $\mathrm{ns}$ & - \\
\hline & \multicolumn{4}{|c|}{ Whole grains (\%) } \\
\hline $0 \mathrm{~kg} \mathrm{ha}^{-1} \mathrm{Ca}$ and $\mathrm{Mg}$ silicate & $\mathrm{y}=-0.0234 \mathrm{x}+49.4541^{*}$ & 0.370 & $y=0.0135 x+54.7975^{*}$ & 0.561 \\
\hline $3,000 \mathrm{~kg} \mathrm{ha}^{-1} \mathrm{Ca}$ and $\mathrm{Mg}$ silicate & $y=-0.0003 x^{2}+0.0182 x+53.0387 *$ & 0.829 & ns & - \\
\hline $6,000 \mathrm{~kg} \mathrm{ha}^{-1} \mathrm{Ca}$ and $\mathrm{Mg}$ silicate & $y=0.0013 x^{2}-0.2716 x+55.3012 *$ & 0.717 & $y=0.0003 x^{2}-0.0615 x+58.7337 *$ & 0.836 \\
\hline \multirow[t]{2}{*}{ 9,000 $\mathrm{kg} \mathrm{ha}^{-1} \mathrm{Ca}$ and $\mathrm{Mg}$ silicate } & $y=-0.0402 x+53.5100^{*}$ & 0.979 & $y=-0.0003 x^{2}+0.0683 x+54.5775^{*}$ & 0.757 \\
\hline & \multicolumn{4}{|c|}{ Vitreous grains $(\%)$} \\
\hline $0 \mathrm{~kg} \mathrm{ha}^{-1} \mathrm{Ca}$ and $\mathrm{Mg}$ silicate & $y=-0.0300 x+45.8830^{*}$ & 0.808 & ns & - \\
\hline 3,000 $\mathrm{kg} \mathrm{ha}^{-1} \mathrm{Ca}$ and $\mathrm{Mg}$ silicate & $y=-0.0494 x+49.7326^{*}$ & 0.891 & ns & - \\
\hline $6,000 \mathrm{~kg} \mathrm{ha}^{-1} \mathrm{Ca}$ and $\mathrm{Mg}$ silicate & $y=0.0009 x^{2}-0.1879 x+50.0506^{*}$ & 0.841 & $\mathrm{~ns}$ & - \\
\hline \multirow[t]{2}{*}{ 9,000 $\mathrm{kg} \mathrm{ha}^{-1} \mathrm{Ca}$ and $\mathrm{Mg}$ silicate } & $y=-0.0508 x+49.9587^{*}$ & 0.872 & $\mathrm{~ns}$ & - \\
\hline & \multicolumn{4}{|c|}{ White-belly grains (\%) } \\
\hline $0 \mathrm{~kg} \mathrm{ha}^{-1} \mathrm{Ca}$ and $\mathrm{Mg}$ silicate & $y=0.00005 x^{2}-0.0132 x+2.9649^{*}$ & 0.955 & $y=0.00004 x^{2}-0.0101 x+1.8894 *$ & 0.897 \\
\hline 3,000 $\mathrm{kg} \mathrm{ha}^{-1} \mathrm{Ca}$ and $\mathrm{Mg}$ silicate & ns & - & $y=-0.0046 x+2.0113^{*}$ & 0.960 \\
\hline $6,000 \mathrm{~kg} \mathrm{ha}^{-1} \mathrm{Ca}$ and $\mathrm{Mg}$ silicate & ns & - & $y=0.00004 x^{2}-0.0118 x+2.0978 *$ & 0.998 \\
\hline \multirow[t]{2}{*}{ 9,000 $\mathrm{kg} \mathrm{ha}^{-1} \mathrm{Ca}$ and $\mathrm{Mg}$ silicate } & $\mathrm{y}=0.00003 \mathrm{x}^{2}-0.0061 \mathrm{x}+2.3108^{*}$ & 0.739 & $y=-0.0045 x+2.0115^{*}$ & 0.942 \\
\hline & \multicolumn{4}{|c|}{ Chalky kernels (\%) } \\
\hline $0 \mathrm{~kg} \mathrm{ha}^{-1} \mathrm{Ca}$ and $\mathrm{Mg}$ silicate & $\mathrm{y}=0.0061 \mathrm{x}+0.9743^{*}$ & 0.967 & $\mathrm{~ns}$ & - \\
\hline 3,000 $\mathrm{kg} \mathrm{ha}^{-1} \mathrm{Ca}$ and $\mathrm{Mg}$ silicate & $y=0.0044 x+0.9135^{*}$ & 0.960 & $\mathrm{~ns}$ & - \\
\hline $6,000 \mathrm{~kg} \mathrm{ha}^{-1} \mathrm{Ca}$ and $\mathrm{Mg}$ silicate & $y=-0.00002 x^{2}+0.0092 x+0.8887 *$ & 0.940 & ns & - \\
\hline 9,000 $\mathrm{kg} \mathrm{ha}^{-1} \mathrm{Ca}$ and $\mathrm{Mg}$ silicate & $\mathrm{y}=0.0084 \mathrm{x}+0.7151^{*}$ & 0.950 & $\mathrm{~ns}$ & - \\
\hline
\end{tabular}

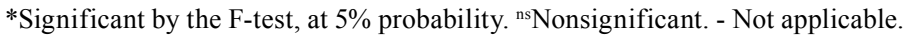



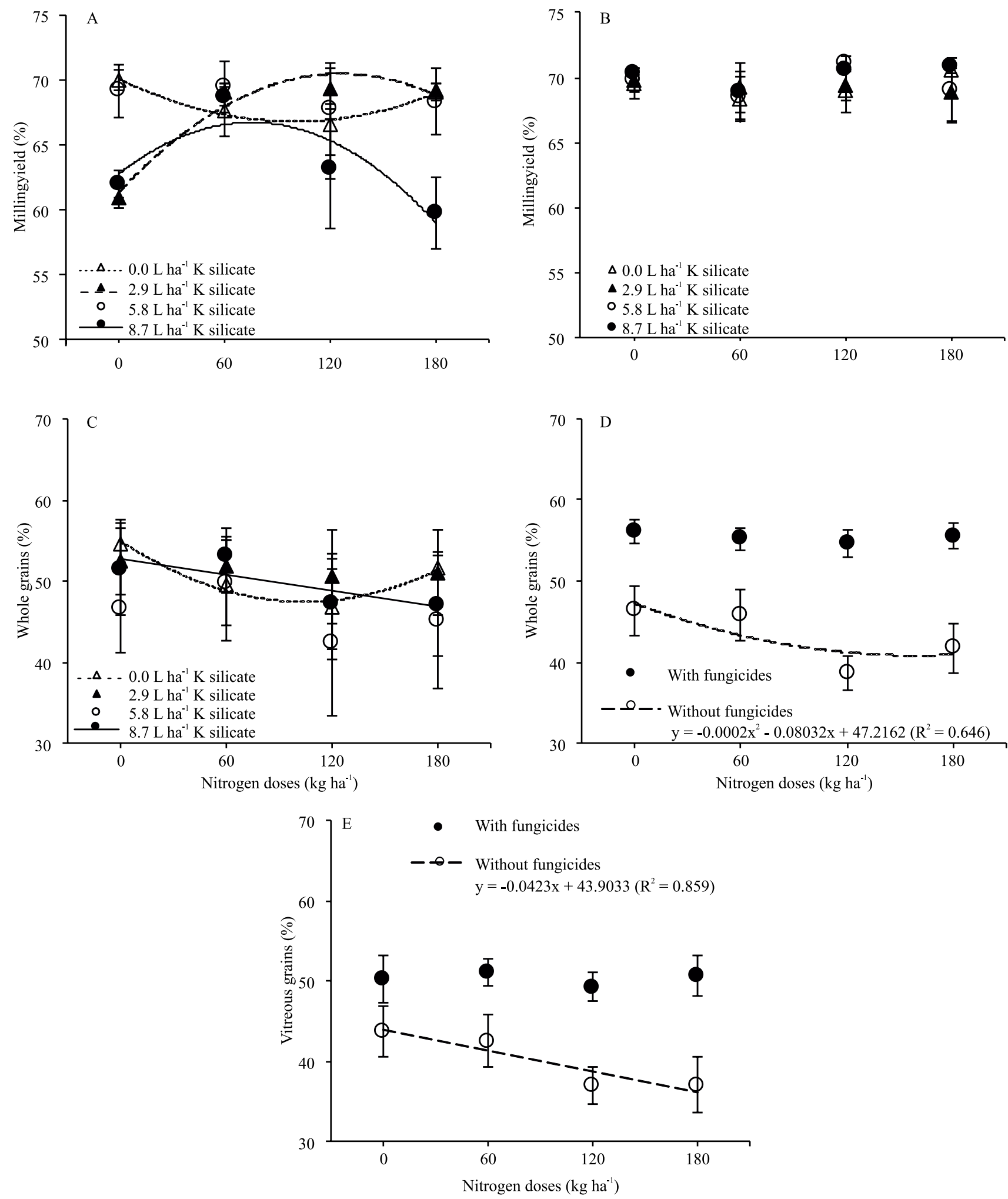

Figure 5. Milling yield (A and B), whole grains (C and D), and vitreous grains (E) for the Guri INTA CL flood-irrigated rice (Oryza sativa) cultivar, according to doses of nitrogen and potassium silicate, without (A) and with (B) fungicide applications in the 2014/2015 crop season. 
grains. The responses of rice plants treated with $\mathrm{Si}$ varied according to the levels of resistance and the different modes of action of each product applied (Nascimento et al., 2018). Furthermore, the x-ray microanalysis showed that the deposition of $\mathrm{Si}$ in rice plants applied via soil occurs on both sides of the leaf, while that of $\mathrm{K}$ silicate occurs only on the adaxial side. This may be one of the possible explanations for the greater disease control when $\mathrm{Si}$ is applied via soil (Rezende et al., 2009).

The occurrence of chalky kernels was influenced by the combination of $\mathrm{N}$ doses and fungicides and of $\mathrm{K}$ silicate doses and fungicides. The percentage of chalky kernels was below $1 \%$ with $\mathrm{N}$ doses associated with fungicides, but above 1\% without fungicides (Figure 6). The chalky area was affected by the doses of $\mathrm{N}$ and of $\mathrm{K}$ silicate, as well as by fungicide applications (Table 3).
Therefore, when there was control of rice blast with fungicides, the percentages of chalky kernels and chalky area were lower. Zhou et al. (2015) evaluated fertilization with $\mathrm{N}$ doses in 351 cultivars of the Indica group, and observed that the percentage of chalky kernels decreased with increasing doses of $\mathrm{N}$ due to the higher accumulation of protein and starch in the grains. In general, the occurrence of panicle blast in field experiments causes reductions in the industrial quality of rice grains.

The characteristics related to grain quality add a higher value of commercialization to the cereal; in the present study, their values remained constant with the use of fungicides, regardless of the application of silicates. The greater the presence of certain parameters, such as white-belly grains, chalky kernels, and chalky area, the lower the consumer's

Table 2. Equations and coefficients of determination $\left(\mathrm{R}^{2}\right)$ of the used regressions, according to nitrogen and potassium silicate doses and to fungicides applied or not to the Guri INTA CL flood-irrigated rice (Oryza sativa) cultivar.

\begin{tabular}{|c|c|c|c|c|}
\hline \multirow[t]{2}{*}{ Treatment } & \multicolumn{2}{|l|}{ Without fungicide application } & \multicolumn{2}{|c|}{ With fungicide application } \\
\hline & Equation & $\mathrm{R}^{2}$ & Equation & $\mathrm{R}^{2}$ \\
\hline & \multicolumn{4}{|c|}{ Milling yield (\%) } \\
\hline $0 \mathrm{~L} \mathrm{ha}^{-1} \mathrm{~K}$ silicate & $y=0.0006 x^{2}-0.1308 x+70.7908 *$ & 0.669 & ns & - \\
\hline 2.9 $\mathrm{L} \mathrm{ha}^{-1} \mathrm{~K}$ silicate & $y=0.0005 x^{2}-0.1457 x+61.2837 *$ & 0.942 & $\mathrm{~ns}$ & - \\
\hline $5.8 \mathrm{~L} \mathrm{ha}^{-1} \mathrm{~K}$ silicate & ns & - & ns & - \\
\hline \multirow[t]{2}{*}{ 8.7 $\mathrm{L} \mathrm{ha}^{-1} \mathrm{~K}$ silicate } & $y=-0.0004 x^{2}+0.0812 x+62.8908 *$ & 0.428 & ns & - \\
\hline & \multicolumn{4}{|c|}{ White-belly grains (\%) } \\
\hline $0 \mathrm{~L} \mathrm{ha}^{-1} \mathrm{~K}$ silicate & $y=-0.0001 x^{2}+0.0259 x+2.2106^{*}$ & 0.563 & ns & - \\
\hline 2.9 $\mathrm{L} \mathrm{ha}^{-1} \mathrm{~K}$ silicate & $y=-0.0001 x^{2}+0.0404 x+1.4812 *$ & 0.886 & $\mathrm{~ns}$ & - \\
\hline $5.8 \mathrm{~L} \mathrm{ha}^{-1} \mathrm{~K}$ silicate & $y=-0.0002 x^{2}+0.0555 x+3.6481 *$ & 0.678 & $\mathrm{y}=-0.0120 \mathrm{x}+3.1137^{*}$ & 0.744 \\
\hline 8.7 $\mathrm{L} \mathrm{ha}^{-1} \mathrm{~K}$ silicate & $y=0.0002 x^{2}-0.0333 x+3.0273 *$ & 0.980 & ns & - \\
\hline
\end{tabular}

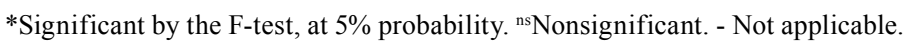

Table 3. Equations and coefficients of determination $\left(\mathrm{R}^{2}\right)$ of the used regressions, according to nitrogen and potassium silicate doses applied to the Guri INTA CL flood-irrigated rice (Oryza sativa) cultivar.

\begin{tabular}{lcc}
\hline Treatment & Equation & $\mathrm{R}^{2}$ \\
\hline & Whole grains (\%) & 0.965 \\
$0 \mathrm{~L} \mathrm{ha}^{-1} \mathrm{~K}$ silicate & $\mathrm{y}=0.0006 \mathrm{x}^{2}-0.1435 \mathrm{x}+54.9657^{*}$ & - \\
$2.9 \mathrm{~L} \mathrm{ha}^{-1} \mathrm{~K}$ silicate & $\mathrm{ns}$ & - \\
$5.8 \mathrm{~L} \mathrm{ha}^{-1} \mathrm{~K}$ silicate & $\mathrm{ns}$ & 0.658 \\
$8.7 \mathrm{~L} \mathrm{ha}^{-1} \mathrm{~K}$ silicate & $\mathrm{y}=-0.0328 \mathrm{x}+52.7128^{*}$ & - \\
\hline & $\mathrm{ns}$ & $\mathrm{ns}$ \\
$0 \mathrm{~L} \mathrm{ha}^{-1} \mathrm{~K}$ silicate & $\mathrm{ns}$ area $(\%)$ & - \\
$2.9 \mathrm{~L} \mathrm{ha}^{-1} \mathrm{~K}$ silicate & $\mathrm{y}=-0.0004 \mathrm{x}^{2}+0.0263 \mathrm{x}+16.7026^{*}$ & - \\
$5.8 \mathrm{~L} \mathrm{ha}^{-1} \mathrm{~K}$ silicate & $\mathrm{ns}$ & - \\
$8.7 \mathrm{~L} \mathrm{ha}^{-1} \mathrm{~K}$ silicate & \multicolumn{2}{c}{} \\
\hline
\end{tabular}

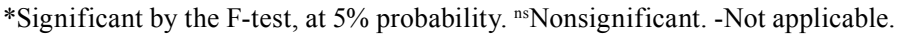



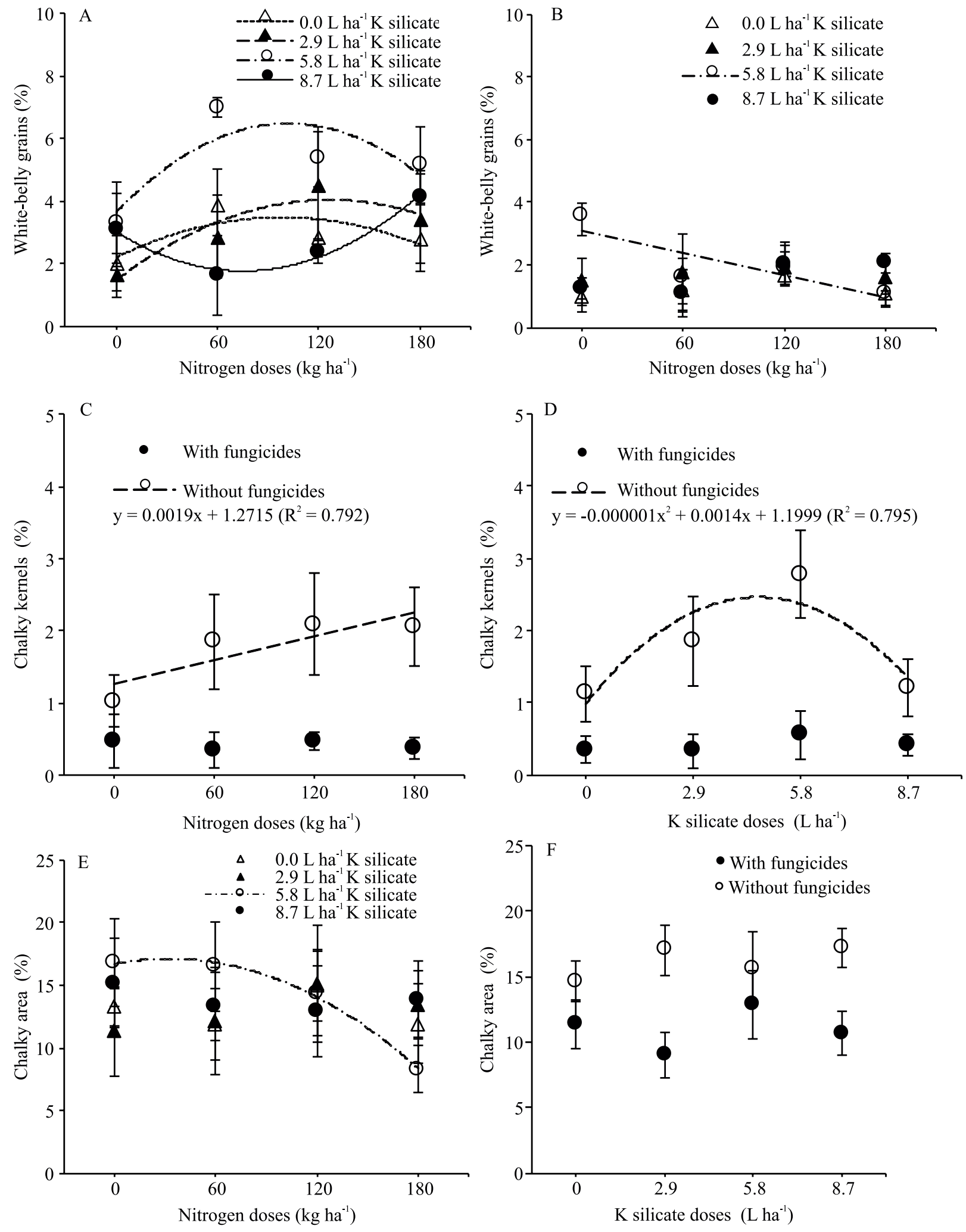

Figure 6. White-belly grains (A and B), chalky kernels (C and D), and chalky area (E and F) for the Guri INTA CL flood-irrigated rice (Oryza sativa) cultivar, according to doses of nitrogen and potassium silicate, without (A) and with (B) fungicide applications in the 2014/2015 crop season. 
acceptance of the product, reducing the amount paid to the producer. The obtained results show that the use of fungicides continues to be the most efficient method to control the disease, especially at high levels of severity. However, the use of silicates mainly via soil has shown to be promising, requiring more studies to prove its efficacy.

\section{Conclusions}

1. The control of rice blast with fungicides keeps the quality of rice (Oryza sativa) grains, milling yield, and the percentages of whole and vitreous grains elevated.

2. Doses above $60 \mathrm{~kg} \mathrm{ha}^{-1}$ nitrogen, without the application of fungicides, decrease the percentage of whole and vitreous grains, but increase the rates of chalky kernels in cultivars sensitive to rice blast.

3. Fertilization with calcium, magnesium silicate, and potassium silicate, without the application of fungicides, has a greater effect on resistance to rice blast, on the occurrence of vitreous grains and chalky kernels, and on milling yield in flood-irrigated rice cultivars sensitive to the disease.

\section{Acknowledgments}

To Coordenação de Aperfeiçoamento de Pessoal de Nível Superior (Capes), for scholarship to the first author.

\section{References}

AHMED, S.; HUMPHREYS, E.; SALIM, M.; CHAUHAN, B.S. Growth, yield and nitrogen use efficiency of dry-seeded rice as influenced by nitrogen and seed rates in Bangladesh. Field Crops Research, v.186, p.18-31, 2016. DOI: https://doi.org/10.1016/j. fcr.2015.11.001.

ALVARES, C.A.; STAPE, J.L.; SENTELHAS, P.C.; GONÇALVES, J.L. de M.; SPAROVEK, G. Köppen's climate classification map for Brazil. Meteorologische Zeitschrift, v.22, p.711-728, 2013. DOI: https://doi.org/10.1127/09412948/2013/0507.

ARTIGIANI, A.C.C.A.; CRUSCIOL, C.A.C.; ARF, O.; ALVAREZ, R. de C.F.; NASCENTE, A.S. Produtividade e qualidade industrial do arroz de terras altas em função da disponibilidade hídrica e adubação. Pesquisa Agropecuária Tropical, v.42, p.340-349, 2012. DOI: https://doi.org/10.1590/ S1983-40632012000300011.

BORDIN, L.C.; CASA, R.T.; MARCUZZO, L.L.; REIS, E.M.; GHELLER, A.; ZANCAN, R.L.; FINGSTAG, M.D. Criticalpoint models to relate yield and disease intensity of the multiple pathosystem in rice leaf spots disease. Ciência Rural, v.46, p.712, 2016. DOI: https://doi.org/10.1590/0103-8478cr20150310.

BRASIL. Ministério da Agricultura, Pecuária e Abastecimento. Instrução Normativa $n^{\circ}$ 6, de 16 de fevereiro de 2009. [Aprova o Regulamento Técnico do Arroz, definindo o seu padrão oficial de classificação, com os requisitos de identidade e qualidade, a amostragem, o modo de apresentação e a marcação ou rotulagem]. Diário Oficial [da] República Federativa do Brasil, 18 fev. 2009. Seção 1, 24p. Available at: <http:// sistemasweb.agricultura.gov.br/sislegis/action/detalhaAto. do? method=visualizarAtoPortal Mapa \& chave $=1687046295>$. Accessed on: May 122016.

BREGAGLIO, S.; TITONE, P.; CAPPELLI, G.; TAMBORINI, L.; MONGIANO, G.; CONFALONIERI, R. Coupling a generic disease model to the WARM rice simulator to assess leaf and panicle blast impacts in a temperate climate. European Journal of Agronomy, v.76, p.107-117, 2016. DOI: https://doi.org/10.1016/j.eja.2016.02.009.

CHEN, Y.; YANG, X.; YUAN, S.K.; LI, Y.F.; ZHANG, A.F.; YAO, J.; GAO, T.C. Effect of azoxystrobin and kresoxim-methyl on rice blast and rice grain yield in China. Annals of Applied Biology, v.166, p.434-443, 2015. DOI: https://doi.org/10.1111/aab.12202.

COUNCE, P.A.; KEISLING, T.C.; MITCHELL, A.J. A uniform, objective, and adaptive system for expressing rice development. Crop Science, v.40, p.436-443, 2000. DOI: https://doi.org/10.2135/ cropsci2000.402436x.

DENG, F.; WANG, L.; PU, S.-L.; MEI, X.-F.; LI, S.-X.; LI, Q.P.; REN, W.-J. Shading stress increases chalkiness by postponing caryopsis development and disturbing starch characteristics of rice grains. Agricultural and Forest Meteorology, v.263, p.4958, 2018. DOI: https://doi.org/10.1016/j.agrformet.2018.08.006.

FANG, C.; HU, X.; SUN, C.; DUAN, B.; XIE, L.; ZHOU, P. Simultaneous determination of multi rice quality parameters using image analysis method. Food Analytical Methods, v.8, p.70-78, 2015. DOI: https://doi.org/10.1007/s12161-014-9870-2.

FERNÁNDEZ, V.; BROWN, P.H. From plant surface to plant metabolism: the uncertain fate of foliar-applied nutrients. Frontiers in Plant Science, v.4, p.1-5, 2013. DOI: https://doi. org/10.3389/fpls.2013.00289.

GRIGG, B.C.; SIEBENMORGEN, T.J.; NORMAN, R.J. Effects of nitrogen rate and harvest moisture content on physicochemical properties and milling yields of rice. Cereal Chemistry, v.93, p.172181, 2016. DOI: https://doi.org/10.1094/CCHEM-06-15-0130-R.

GROTH, D.E. Azoxystrobin rate and timing effects on rice head blast incidence and rice grain and milling yields. Plant Disease, v.90, p.1055-1058, 2006. DOI: https://doi.org/10.1094/pd-90-1055.

HAO, Z.; WANG, L.; LI, C.; HUANG, F.; TAO, R. Comparison between the resistance to blast in panicles exserted from the main culm and primary tillers as measured in six rice varieties. European Journal of Plant Pathology, v.138, p.9-14, 2014. DOI: https://doi.org/10.1007/s10658-013-0305-5.

HOSSAIN, M.; ALI, M.A.; HOSSAIN, M.D. Occurrence of blast disease in rice in Bangladesh. American Journal of Agricultural Science, v.4, p.74-80, 2017. 
HUANG, H.; THU, T.N.T; HE, X.; GRAVOT, A.; BERNILLON, S.; BALLINI, E.; MOREL, J.-B. Increase of fungal pathogenicity and role of plant glutamine in Nitrogen-Induced Susceptibility (NIS) to rice blast. Frontiers in Plant Science, v.8, art.265, 2017. DOI: https://doi.org/10.3389/fpls.2017.00265.

IRGA. Instituto Riograndense do Arroz. Custo de produção médio ponderado do arroz irrigado do Rio Grande do Sul safra 2017/18. 2018. Available at: <http://stirga2018-admin. hml.rs.gov.br/upload/arquivos/201805/18160831-custo-120180115091236custo-2017-18.pdf>. Accessed on: Mar. 122018.

KORNDÖRFER, G.H.; DATNOFF, L.E. Adubação com silício: uma alternativa no controle de doenças da cana-de-açúcar e do arroz. Informações Agronômicas, v.70, p.1-5, 1995.

LIMA, M. de A.; CASTRO, V.F. de; VIDAL, J.B.; ENÉAS-FILHO, J. Aplicação de silício em milho e feijão-de-corda sob estresse salino. Revista Ciencia Agronômica, v.42, p.398-403, 2011.

LONDERO, G.P.; MARCHESAN, E.; PARISOTTO, E.; COELHO, L.L.; ARAMBURU, B.B.; FLORES, C.S.; SILVA, A.L. da. Qualidade industrial de grãos de arroz decorrente da supressão da irrigação e umidade de colheita. Irriga, v.20, p.587601, 2015. DOI: https://doi.org/10.15809/irriga.2015v20n3p587.

MINGOTTE, F.L.C.; HANASHIRO, R.K.; FORNASIERI FILHO, D. Características físico-químicas do grão de cultivares de arroz em função da adubação nitrogenada. Semina: Ciências Agrárias, v.33, p.2605-2618, 2012. DOI: https://doi. org/10.5433/1679-0359.2012v33n6Supllp2605.

NAKATA, M.; FUKAMATSU, Y.; MIYASHITA, T.; HAKATA, M.; KIMURA, R.; NAKATA, Y.; KURODA, M.; YAMAGUCHI, T.; YAMAKAWA, H. High temperature-induced expression of rice $\alpha$-amylases in developing endosperm produces chalky grains. Frontiers in Plant Science, v.8, p.1-13, 2017. DOI: https://doi. org/10.3389/fpls.2017.02089.

NASCIMENTO, A.M.; ASSIS, F.A.; MORAES, J.C.; SOUZA, B.H.S. Silicon application promotes rice growth and negatively affects development of Spodoptera frugiperda (J. E. Smith). Journal of Applied Entomology, v.142, p.241-249, 2018. DOI: https://doi.org/10.1111/jen.12461.

OU, S.H. Rice diseases. 2ed. Kew: Commonwealth Mycological Institute, 1985. 380p.

PAK, D.; YOU, M.P.; LANOISELET, V.; BARBETTI, M.J. Azoxystrobin and propiconazole offer significant potential for rice blast (Pyricularia oryzae) management in Australia. European
Journal of Plant Pathology, v.148, p.247-259, 2017. DOI: https:// doi.org/10.1007/s10658-016-1084-6.

REIS, M.A. dos; ARF, O.; SILVA, M.G. da; SÁ, M.E. de; BUZETTI, S. Aplicação de silício em arroz de terras altas irrigado por aspersão. Acta Scientiarum. Agronomy, v.30, p.37-43, 2008. DOI: https://doi.org/10.4025/actasciagron.v30i1.1126.

REUNIÃO TÉCNICA DA CULTURA DO ARROZ IRRIGADO, 30., 2014, Bento Gonçalves. Arroz irrigado: recomendações técnicas da pesquisa para o Sul do Brasil. Santa Maria: SOSBAI, 2014. 189p.

REUNIÃO TÉCNICA DA CULTURA DO ARROZ IRRIGADO, 30., 2014, Farroupilha. Arroz irrigado: recomendações técnicas da pesquisa para o Sul do Brasil. Cachoeirinha: SOSBAI, 2018. 205p.

REZENDE, D.C.; RODRIGUES, F.Á.; CARRÉ-MISSIO, V.; SCHURT, D. A.; KAWAMURA, I.K.; KORNDÖRFER, G.H. Effect of root and foliar applications of silicon on brown spot development in rice. Australasian Plant Pathology, v.38, p.6773, 2009. DOI: https://doi.org/10.1071/AP08080.

SANTOS, H.G. dos; JACOMINE, P.K.T.; ANJOS, L.H.C. dos; OLIVEIRA, V.A. de; LUMBRERAS, J.F.; COELHO, M.R.; ALMEIDA, J.A. de; CUNHA, T.J.F.; OLIVEIRA, J.B. de. Sistema brasileiro de classificação dos solos. 3.ed. rev. e ampl. Brasília: Embrapa, 2013. 353p.

SILVA-LOBO, V.L.; FILIPPI, M.C.C.; SILVA, G.B.; VENANCIO, W.L.; PRABHU, A.S. Relação entre o teor de clorofila nas folhas e a severidade de brusone nas panículas em arroz de terras altas. Tropical Plant Pathology, v.37, p.83-87, 2012. DOI: https://doi. org/10.1590/S1982-56762012000100011.

STRECK, E.A.; MAGALHÃES JÚNIOR, A.M. de; AGUIAR, G.A.; FACCHINELLO, P.H.K.; PERIN, L.; FAGUNDES, P.R.R.; OLIVEIRA, A.C. de. Genetic progress of grain quality of floodedirrigated rice cultivars in the state of Rio Grande do Sul, Brazil. Pesquisa Agropecuária Brasileira, v.53, p.453-463, 2018. DOI: https://doi.org/10.1590/S0100-204X2018000400007.

TELÓ, G.M.; MARCHESAN, E.; FERREIRA, R.B.; LÚCIO, A.D.; SARTORI, G.M.S.; CEZIMBRA, D.M. Qualidade de grãos de arroz irrigado colhidos com diferentes graus de umidade em função da aplicação de fungicida. Ciência Rural, v.41, p.960-966, 2011. DOI: https://doi.org/10.1590/s0103-84782011000600007.

ZHOU, L.; LIANG, S.; PONCE, K.; MARUNDON, S.; YE, G.; ZHAO, X. Factors affecting head rice yield and chalkiness in indica rice. Field Crops Research, v.172, p.1-10, 2015. DOI: https://doi.org/10.1016/j.fcr.2014.12.004. 